\title{
ESTÉTICAS DAS RESISTÊNCIAS E O DOCUMENTÁRIO: DIÁRIO DE EXUS
}

\author{
Gilberto Alexandre Sobrinho \\ Universidade Estadual de Campinas \\ gilsobrinho@iar.unicamp.br
}

\begin{abstract}
RESUMO
De 2013 a 2016, foram desenvolvidos três projetos de documentário sob minha direção, na região metropolitana de Campinas-SP, que resultaram na "Trilogia Afro-Campineira". São três curtasmetragens focados em protagonistas de processos culturais, religiosos e artísticos, todos defensores de manifestações de matrizes africanas e seus potentes hibridismos. Os filmes são Diário de Exus (2015), A Dança da Amizade, Histórias de Urucungos, Puítas e Quijengues (2016) e A Mulher da Casa do Arco-Íris (2017/2018). Todos os filmes tiveram fontes de financiamento como FAEPEX/UNICAMP, FICC e Prêmio Estimulo ao Curta-metragem do Estado de São Paulo e contaram com uma rede de parceiros, da universidade (UNICAMP) e das comunidades e pontos de cultura envolvidos. Desenvolvem-se, nos filmes, o que nomeio como as "estéticas das resistências", priorizando narrativas afro-diaspóricas, num processo de criação em que confluem estética e política. Esteticamente, trata-se de destacar a convergência e a disputa dos modos observativos, participativos, poéticos e performáticos de realização documentárias, voltados para sujeitos portadores de códigos culturais afrocentrados. Politicamente, realçam-se o papel da cultura e da religião na afirmação e construção identitária do negro, no Brasil. Esse texto documenta o processo de realização do primeiro curta-metragem, Diário de Exus.
\end{abstract}

Palavras-chave:

\section{SOBRE A TRILOGIA E O PROCESSO DE CONSTRUÇÃO DA (AUTO) IMAGEM NO DOCUMENTÁRIO: O OUTRO QUE ME HABITA}

Imbricamentos entre questões identitárias e documentário estão no horizonte de minhas pesquisas acadêmicas, realizações artísticas e atividades didáticas. Assim, ao lado dos estudos acadêmicos sobre documentários, fizeram muita diferença o meu recente engajamento com a direção de documentários, centrados em temas da cultura afro-brasileira, em Campinas. Vale destacar que todo esse processo de realização implicou em amplas vivências comunitárias, desdobrando-se em relações afetivas potentes que incrementaram o sentido das narrativas.

O início se deu em 2013, com a realização do documentário em que o motivo principal foi o registro de uma peça de teatro sobre o orixá Exu, a ser encenada pelo Grupo Pindorama ${ }^{1}$, sendo a mesma

\footnotetext{
${ }^{1}$ https://www.grupopindorama.com/, acessado em 31 de maio de 2019.
} 
encomendada por Mestre Jahça, homem negro, funcionário aposentado da Unicamp do Instituto de Artes e que se identifica profundamente com essa divindade. Do convívio com Jahça, uma rede de afetos emergiu e, assim, de forma intensa, brotou a vontade de lançar um olhar cinemático sobre a cidade de Campinas, sob o ponto de vista de homens e mulheres negras que edificaram um gigante território potente e diversificado. Diário de Exus $(2015)^{2}$, filme que resultou desse trabalho, demonstra, em primeiro lugar, o meu modo de documentar com utilização de várias texturas de imagens videográficas, som direto, imagens de arquivo, depoimento e registro de eventos e acontecimentos. Algo que aponta para um olhar em construção mosaicada que define, pela imagem, os territórios negros da cidade.

IMAGEM 01- Mestre Jahça em Diário de Exus

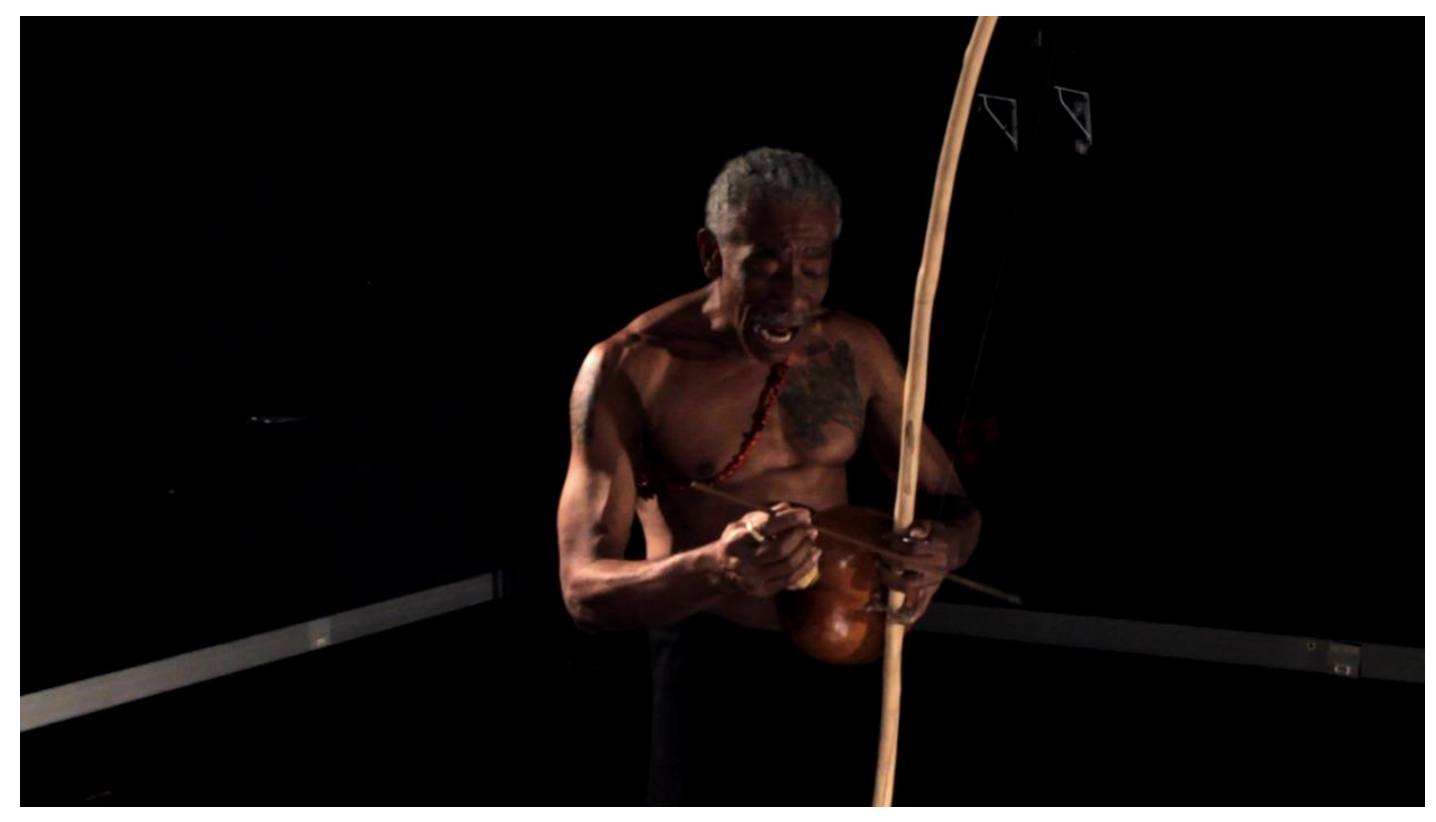

Desse processo, cheguei no grupo Urucungos, Puítas e Quijengues e outro projeto em fina conexão com anterior começou a se esboçar. À medida que a equipe ia se aproximando dos territórios e das pessoas, pudemos perceber a rede de comunidades que se forma em defesa de um vasto vocabulário religioso, cultural e artístico afro-brasileiro. As amizades foram se tecendo e isso eu penso que está em cada imagem do filme. Além do registro do processo de documentação e da obsessão pela restituição dos momentos que compartilhamos, o filme revela também essa troca de

${ }^{2}$ Disponível em https://www.youtube.com/watch?v=EDOzUro7EDs, acessado em 31 de maio de 2019. 


\section{$(\infty)$ EY}

afetos, de amizade e de conhecimento. Em A Dança da Amizade. Histórias de Urucungos, Puítas e Quijengues (2016), o que o espectador vê é o transbordamento dessas relações, valorizado por meio de depoimentos de personagens históricos que estiveram no grupo desde o seu início, todos negros, bem como registros de apresentações variadas de eventos de cultura popular como algo vivo, dinâmico e extrapola fronteiras.

IMAGEM 02 - Raquel Trindade em A Dança da Amizade.

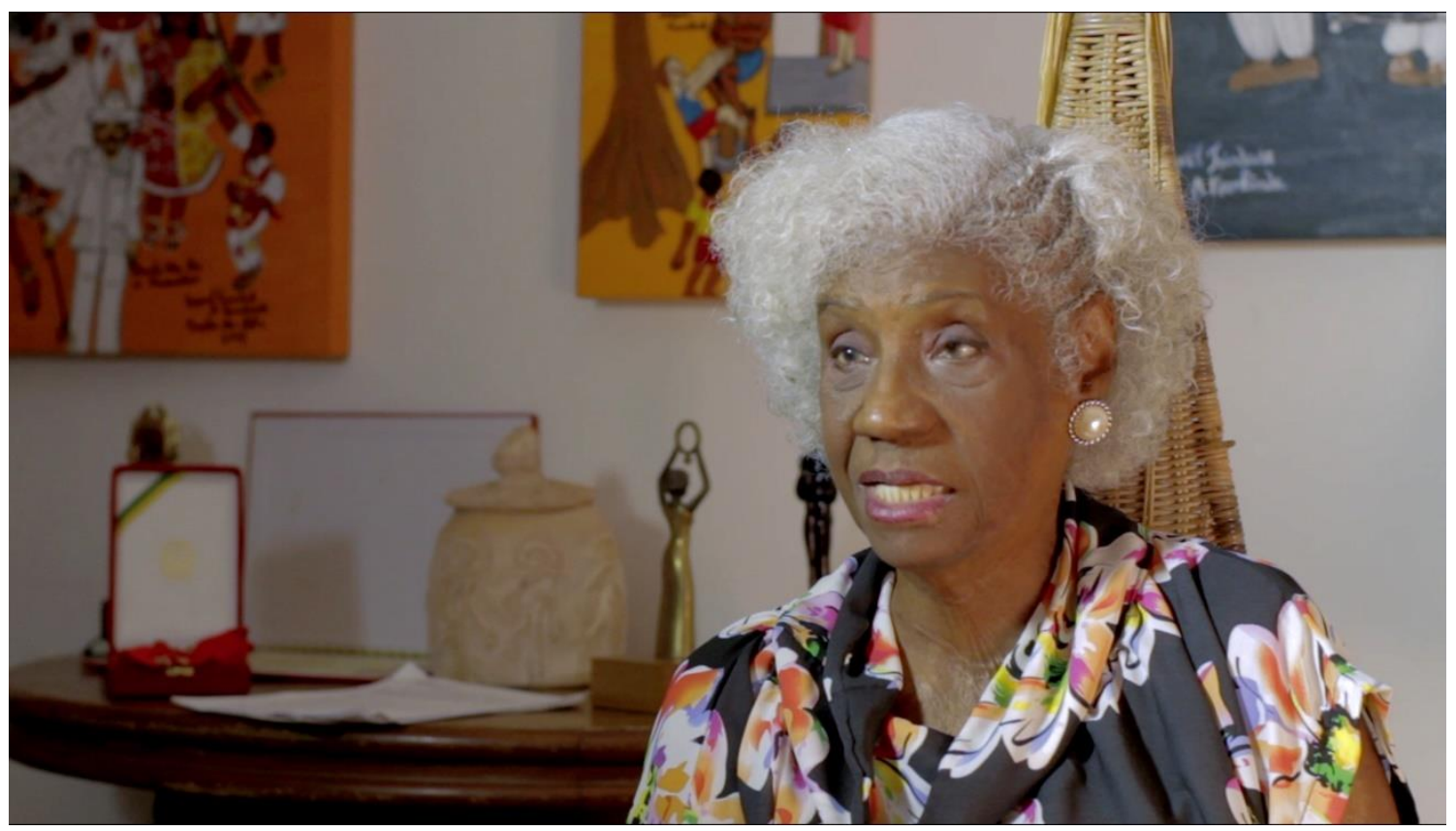

Desde 2013, filmo a Lavagem da Escadaria da Catedral de Campinas. Esse evento, organizado por duas influentes Yalorixás da região, Mãe Dango e Mãe Corajacy, já avança décadas e é bastante representativo da força ancestral afro-brasileira. Nele, religiosos e praticantes da cultura negra em várias frentes descem, simbolicamente, a Rua 13 de maio com água de cheiro e flores e ocupam a área externa frontal da Catedral. Trata-se de um eventos agregador, simbolicamente importante para compreender a trama dos grupos afro-brasileiros em Campinas e região, sendo o encontro que acontece todo sábado de aleluia, um momento marcante para firmar laços e adensar as redes. 
IMAGEM 03 - Mãe Dango ao centro em A Mulher da Casa do Arco-Iris

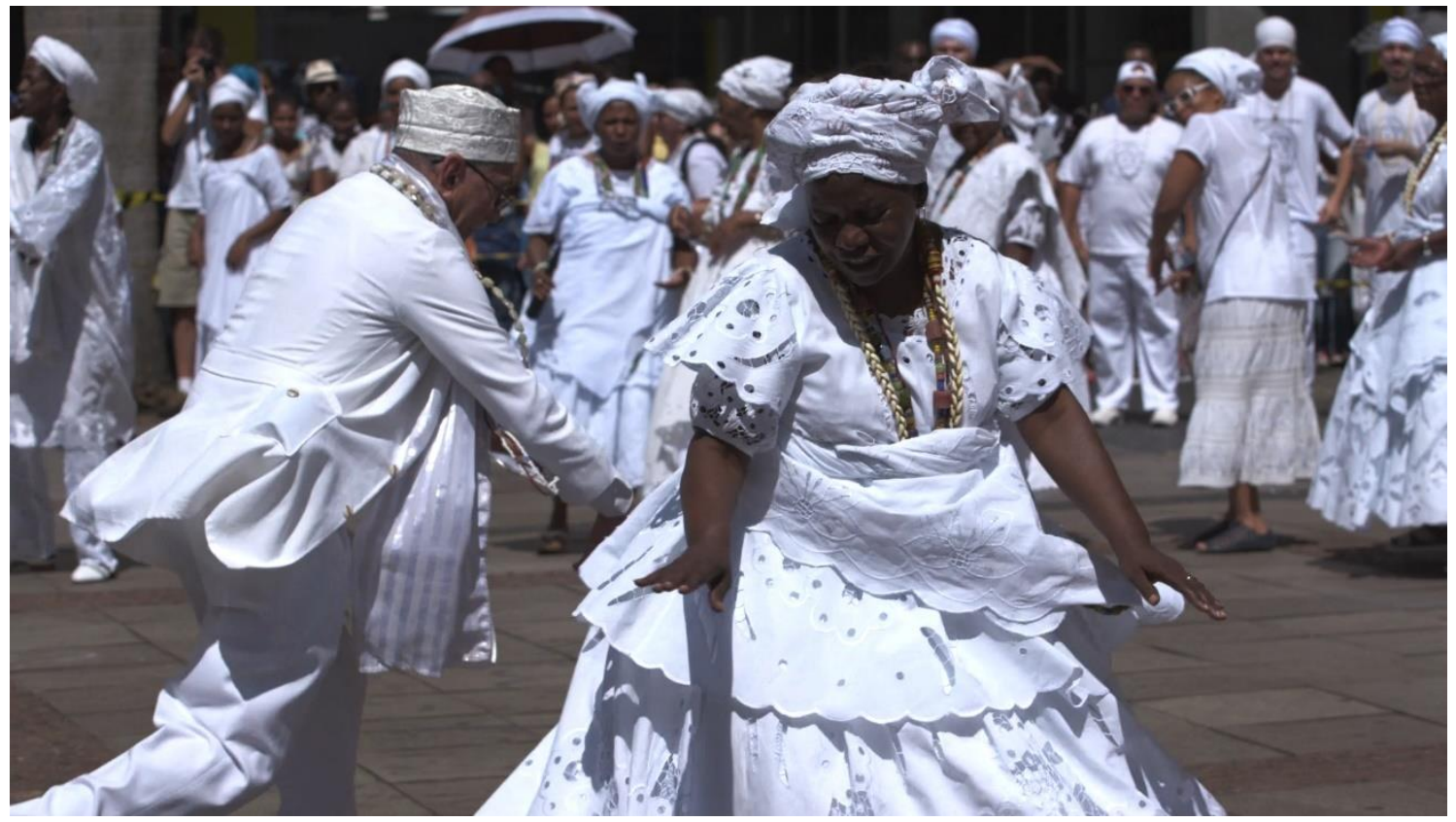

A necessidade de dar um fechamento para essa fase de encontros com essa Campinas negra, incidiu-se na produção de mais um documentário. Mãe Dango convenceu-se de que sua história poderia ser narrada por mim e pela minha equipe e assim, nasceu A Mulher da Casa do Arco-Íris, um documentário fortemente poético, numa montagem rítmica, e uma trilha elaborada a partir dos sons vivenciados. Resulta desse processo, a importância de continuar narrando sobre a identidade, assumidamente como uma construção de vários níveis. No caso desses filmes, à medida que os filmes foram nascendo, comecei a perceber que o princípio da exterioridade marcante era um véu que se descortinava gradativamente. $\mathrm{Eu}$, um sujeito pardo, percebi que reativava memórias ancentrais profundas, o que me conectava profundamente com todas essas histórias e essas pessoas. Portanto, não era um sujeito reportando-se à alteridade, era um processo de representação que se encaminhava para o que passou a ser o mote da realização: o outro que me habita, a comunhão entre realizadores, participantes, imagens e sons. O presente Documento é o primeiro de uma série que visa compartilhar as experiências dessas realizações. 
O PROCESSO DE CRIAÇÃo, PRODUÇÃo E DIFUSÃo DE DIÁRIO DE EXUS (20132015)

\section{IMAGEM 04 - Cartaz de Diário de Exus (arte de Claudia Kfouri)}

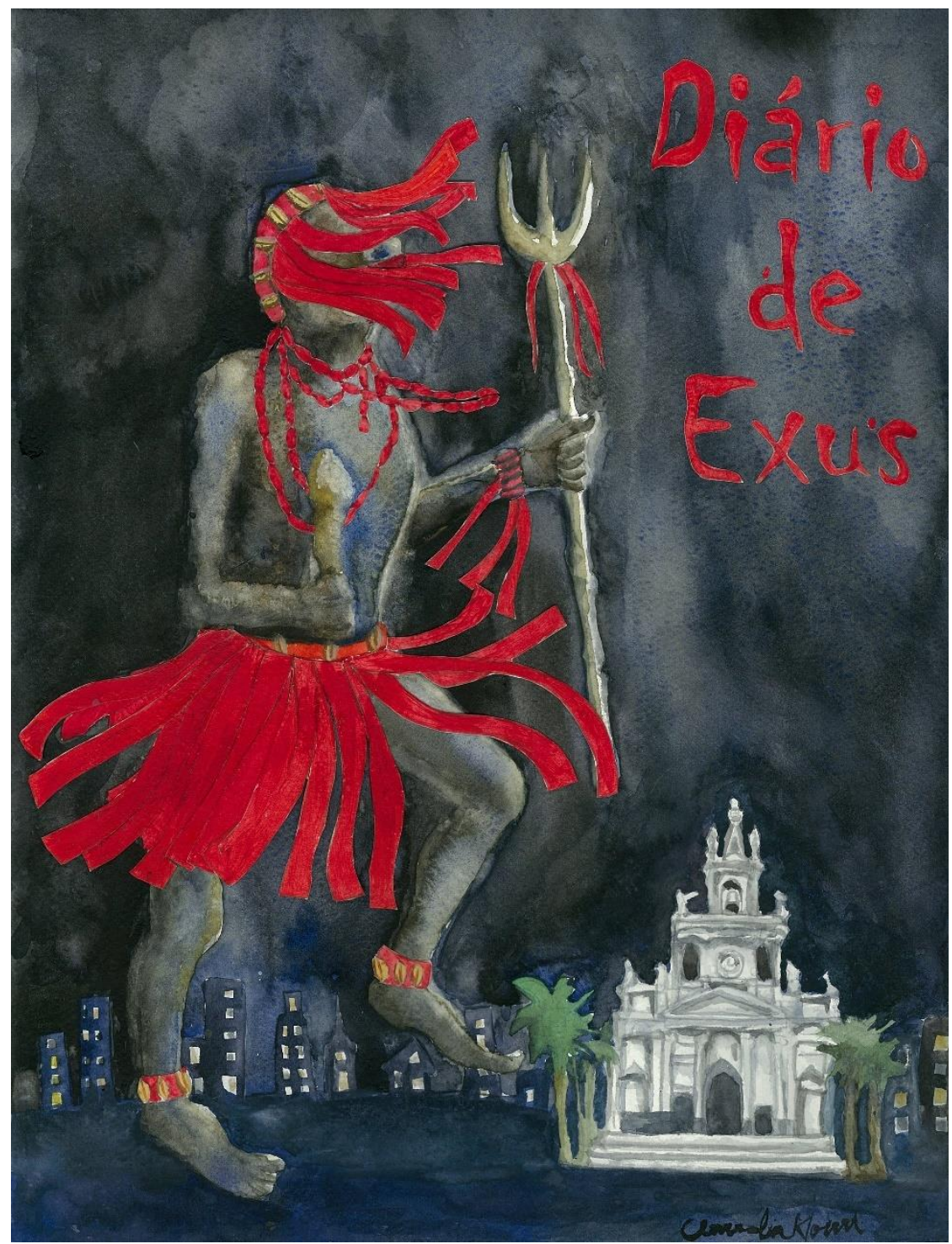

Após o retorno de uma imersão profunda em Salvador, em janeiro de 2013, onde deixei-me impregnar por todos os possíveis signos, sabores, paisagens, cheiros e sons sotepolitanos, fui almoçar com uma colega e amiga do Instituto de Artes, Grácia Navarro. Ela me conta que estava começando a montagem de uma peça teatral sobre o orixá Exu, com o Mestre Jahça, funcionárioartista que estava se aposentando. O motivo da conversa era um convite para que eu dirigisse um documentário, a partir dessa encenação. Eu disse a ela que não era cineasta, ela, então, me devolveu 
com o que seria um disparador dos meus recentes ofícios: "Mas então, você pode passar a ser", foi a resposta dela.

Mãos à obra. Aceitei prontamente o convite, montei uma equipe formada por estudantes da graduação em Midialogia e mestrado em Multimeios, e contei também com a colaboração para a produção de Alessandro Oliveira, meu companheiro. Para o desenvolvimento do projeto, tive o privilégio de ter a consultoria da cineasta argentina Lucrécia Martel. E foi justamente para curta residência com ela que realizei a primeira entrevista que transcrevo a seguir.

Gilberto - Mestre, eu gostaria que o senhor se apresentasse; em primeiro lugar, que o senhor dissesse o seu nome e o que o senhor faz aqui na Unicamp.

Mestre Jahça - Meu nome é Jacinto Rodrigues da Silva, eu atualmente eu sou profissional em arte, cultura e comunicação, no Instituto de Artes, da Universidade de Campinas. Eu entrei aqui com 14 anos, né, patrulheiro mirim, trabalhei no bandejão 25 anos, aí tive a oportunidade de vir para o departamento de Artes Cênicas, agora vou completar quarenta anos e tô aposentando nessa função. E... pra mim, foi uma vitória né, de quando entramo aqui na universidade, não tinha nem dimensão de como seria a construção da minha vida, desse processo de ser gente. E eu tô contente né, com essa caminhada, com o que eu alcancei né, com o dia a dia que me levou até o dia de hoje.

Gilberto - E que tipo de processo artístico o senhor desenvolve aqui?

Mestre Jahça - Atualmente eu desenvolvo o trabalho de expressão corporal com os meninos né, com a capoeira eles buscam o arquétipo né, que é criar o mandingueiro... como se fosse um clown, como Charles Chaplin desenvolveu o Carlitos, e outras personagens envolvem os seus clowns né... O capoeirista ele tem um clown, então o objetivo da capoeira é desenvolver no ator, buscar através do jogo, dos trejeitos, o clown do artista, através de movimentos né.

Gilberto - Nós estamos juntos, Mestre, num espetáculo que é s obre o Exu. O Exu no imaginário brasileiro. $O$ que significa para o senhor fazer parte desse espetáculo nesse momento?

Mestre Jaça - O Exu, assim, como todo cidadão né que vem de uma educação cristã né, na infância, tem toda uma situação. Até um tempo para mim ele era misterioso, do mal né, durante muito tempo da minha vida né eu tinha ele também como... uma certa vergonha, um certo receio, principalmente por ser de tez negra, de origem negra, então eu tinha vergonha do Exu e também não tinha o conhecimento dessa energia né, do que seria o Exu dentro do... então... eu evitava muito né, tudo que viesse... do lado negro né... do imaginário do mal. Mas a partir do contato com a mestra Raquel Trindade, que montou em 1988 o grupo Urucungos, Puítas e Quijengues, e a função era montar... fazer o 100 anos de abolição e nesse envolvimento com ela desenvolveu o candomblé e explicou para nós a função de cada orixá. E na época ela olhou para mim, para o Joãozinho e para o Alceu e falou vocês vão ser o Exu, aí ela explicou pra nós qual era o Exu na visão dela do Candomblé né, que é o orixá da fertilização, que fertilizou a terra, o cosmo né, através de... e tem o falo, o falo é seu poder de força né, de energia, 
mas é uma energia cósmica, e sem ele os outros orixás não tem nenhuma função objetiva né, ele é o primeiro orixá, é o primeiro a ser tratado, mas também não é o demônio, ele é... sem ele não acontece nada, então vi e percebi a outra história né, que tinha sido apagada da minha mente né... Então comecei a pesquisar, fazer mais trabalhos referentes ao Exu, referente à minha cultura, à minha história, minha origem e hoje eu tenho orgulho né, de representar essa energia né, de fazer com que ela seja desmistificada, através da arte e da cultura, mas são muitas coisas, muita caminhada pra fazer né, disso porque é muita, entre nós há muita, não é negatividade, nossa cultura é cheia de histórias, de ritos e mitos, e é isso que me faz desenvolver esse trabalho hoje, com mais certeza, com mais pegada, mais sabedoria né, e também tô aprendendo nesse envolvimento né que a gente tá tendo, mais sobre esse orixá, mais sobre essa essência. ${ }^{3}$

IMAGEM 05 - Raquel Trindade, Alceu, Joãozinho e Jahça, apresentação de Exu (acervo pessoal de Mestre Jahça)

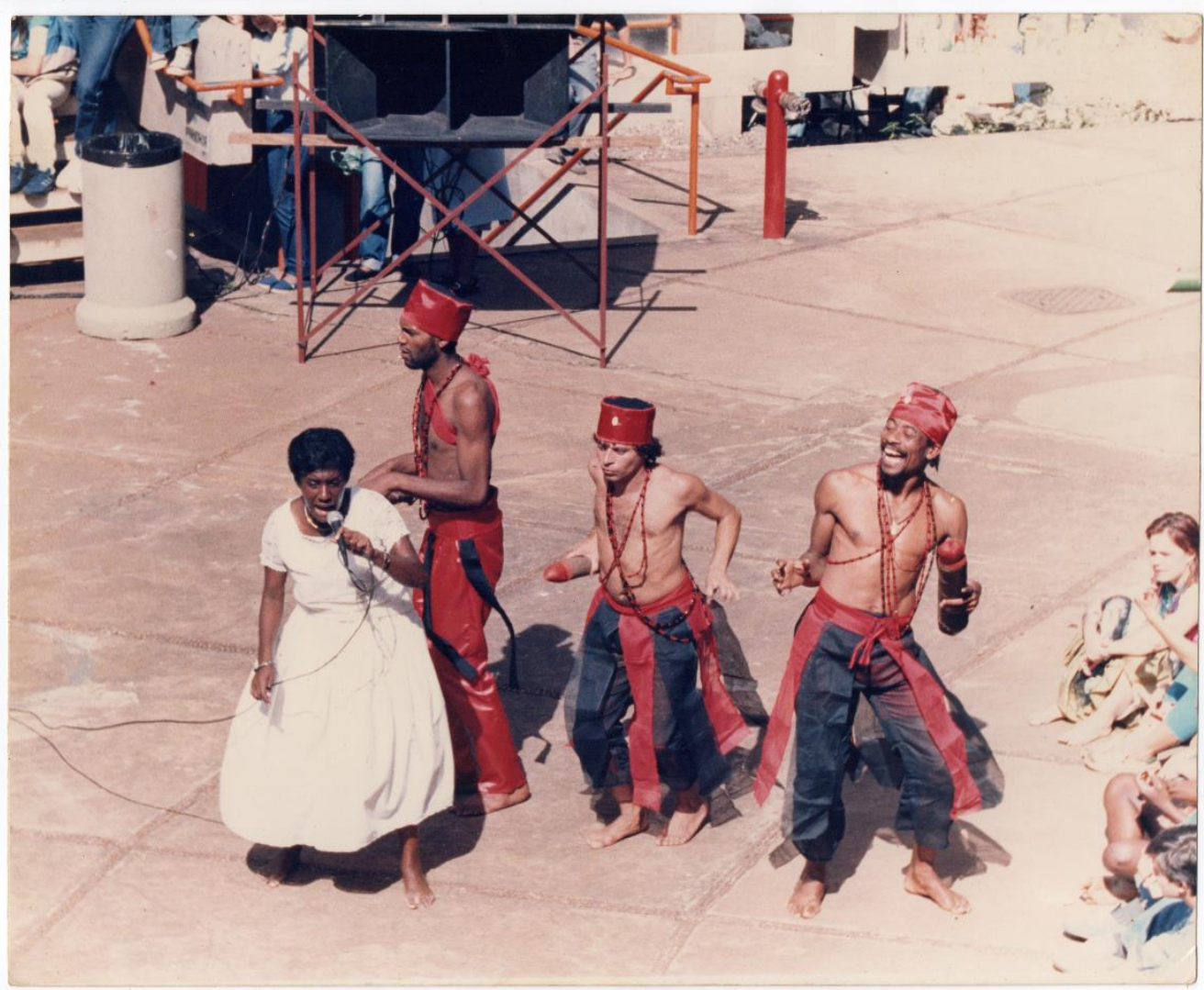

\footnotetext{
${ }^{3}$ Transcrição de uma entrevista realizada para um laboratório de criação, conduzido pela cineasta argentina Lucrécia Martel, o material foi transcrito e analisado para o livro Conversas Sobre uma Ficção Viva, organizado por Rafael Urban e Marcelo Munhoz (Curitiba, Imagens da Terra, 2013), disponível no link: https://issuu.com/tambormultiartes/docs/livro_web
}

Rev. Iberoam. Patrim. Histórico-Educativo, Campinas (SP), v. 5, p. 1-26, e019041, 2019. 
Nessa conversa, surgiram várias pistas que passamos a seguir. $\mathrm{O}$ motivo central para a realização do documentário foi o acompanhamento do processo de montagem do espetáculo teatral intitulado "Exus", sob a direção de Grácia Navarro, dramaturgia de Isa Kopelman, com o Grupo Pindorama. O documentário foi pensado a partir da observação do processo criativo da montagem teatral, que envolveu o trabalho dos atores e de uma atriz e todo o expediente de encenação para dar corpo a Exu, a reflexão sobre o mesmo em um seminário acadêmico aberto ao público, entrevistas, filmagem em eventos e espaços na cidade de Campinas que trouxeram atualidade a esse orixá e pesquisa em arquivos tais como Centro de Memória e SIARQ (Arquivo Central), ambos da Unicamp, Museu do Café de Campinas e os arquivos pessoais de fotografia e vídeo de Mestre Jahça.

IMAGEM 05- Grácia Navarro (still de Diário de Exus)

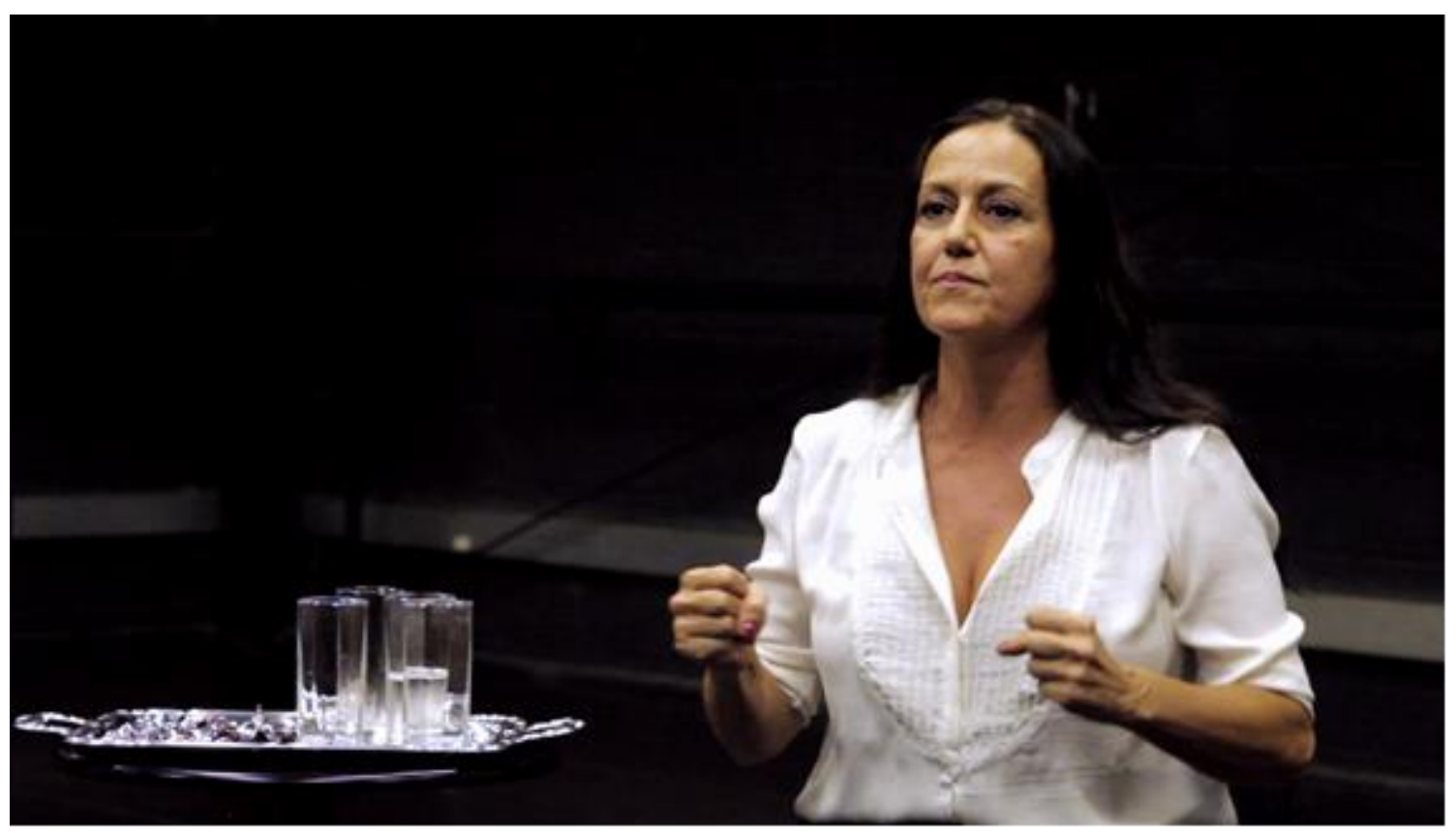

Exu veio para o Brasil junto com o patrimônio cultural dos africanos que aqui chegaram como escravos e foi transmutado pela cultura dominante em demônio. Exu é uma entidade cultuada nos terreiros de Umbanda e Candomblé. Ao lidar com um tema diretamente relacionado com a produção simbólica dos africanos e dos seus descendentes, tínhamos, consequentemente, um motivo caro à compreensão da formação cultural do Brasil. O universo populacional dos afrodescendentes ultrapassa cinquenta por cento da população, no entanto, do ponto de vista das 
representações simbólicas, a herança africana ainda não goza da legitimidade que lhe é de direito. A associação com o demônio continua sendo uma forma ideológica de manutenção da discriminação religiosa e racial. Neste sentido, o documentário (bem como o espetáculo teatral) buscaram tratar das representações, conceitos e iconografia relacionada ao Orixá Exu, no imaginário brasileiro. Diante da dimensão estética e política da questão, o interesse era enfatizar que estávamos lidando com algo vivo. Mestre Jahça, capoeirista, ator e bailarino era, assim, o fio condutor entre a herança patrimonial e os cultos religiosos afro-brasileiros.

Funcionário aposentado da Unicamp, esse senhor, o centro do espetáculo, foi também o "personagem" principal do documentário. Seu corpo, ao mesmo tempo viril e envelhecido, traduz o tempo e as camadas de história, sua dança e sua atuação teatral restituem as tradições da cultura afro-brasileira e sua inserção no ambiente acadêmico potencializou, assim, um campo de forças entre saberes e as tensões do racismo estrutural do Brasil. Partindo da fala e da história de vida de Mestre Jahça, que encontrou na arte o componente de empoderamento e identidade, o documentário inspecionou, por meio de imagens, seu passado pessoal. Isso resultou em uma narrativa relacionada com a cidade de Campinas, as experiências de trabalho, de racismo e de produção artística na Unicamp e também aproximou-o de outros afrodescendentes que possuem uma trajetória de luta contra o preconceito racial no mesmo contexto urbano. Assim, incluiu-se uma entrevista com o escritor, ator e diretor Natanael dos Santos, do Grupo Liberdade Canto \& Dança, performance do grupo de hip hop A Rua'nda, filmagem da Lavagem da Escadaria da Catedral Nossa Senhora da Conceição - Campinas, imagens de estátuas, obras de artes e outros arquivos para proporcionar uma ponte entre o legado do passado e a vivência afro-brasileira no tempo presente.

Os procedimentos de filmagem e o estabelecimento de uma estrutura prévia para a montagem final assentam-se sobre o conceito de um diário em que se reúnem diferentes registros relacionados sobre Exu, de modo a compor uma imagem prismática, pessoal e intimista de todo o processo. O documentário tem duração de 24 minutos. Em sua elaboração final, temos uma narrativa audiovisual que conjuga o registro pessoal da filmagem da peça e as imagens e sons conectados com a história viva desse legado, sendo o conteúdo dessas imagens exteriores ao espetáculo diretamente vinculadas com pessoas, eventos e espaços da região metropolitana de Campinas. O formato final privilegia, assim, uma "escrita" fragmentada de imagens e sons, um deslizar na superfície de imagens organizadas pelo viés fortemente subjetivo de sua enunciação, 


\section{$(\mathrm{cc})$ EY}

que valoriza o registro desses vários encontros. Um documentário que visa capturar e organizar narrativas, saberes, iconografia, corpos, espaços, paisagens e sons afrocentrados num território específico: a cidade de Campinas.

Imagens do processo de realização (pesquisa em arquivos):

IMAGEM 06 - Centro de Campinas, Diário de Exus (Fotografia V8)

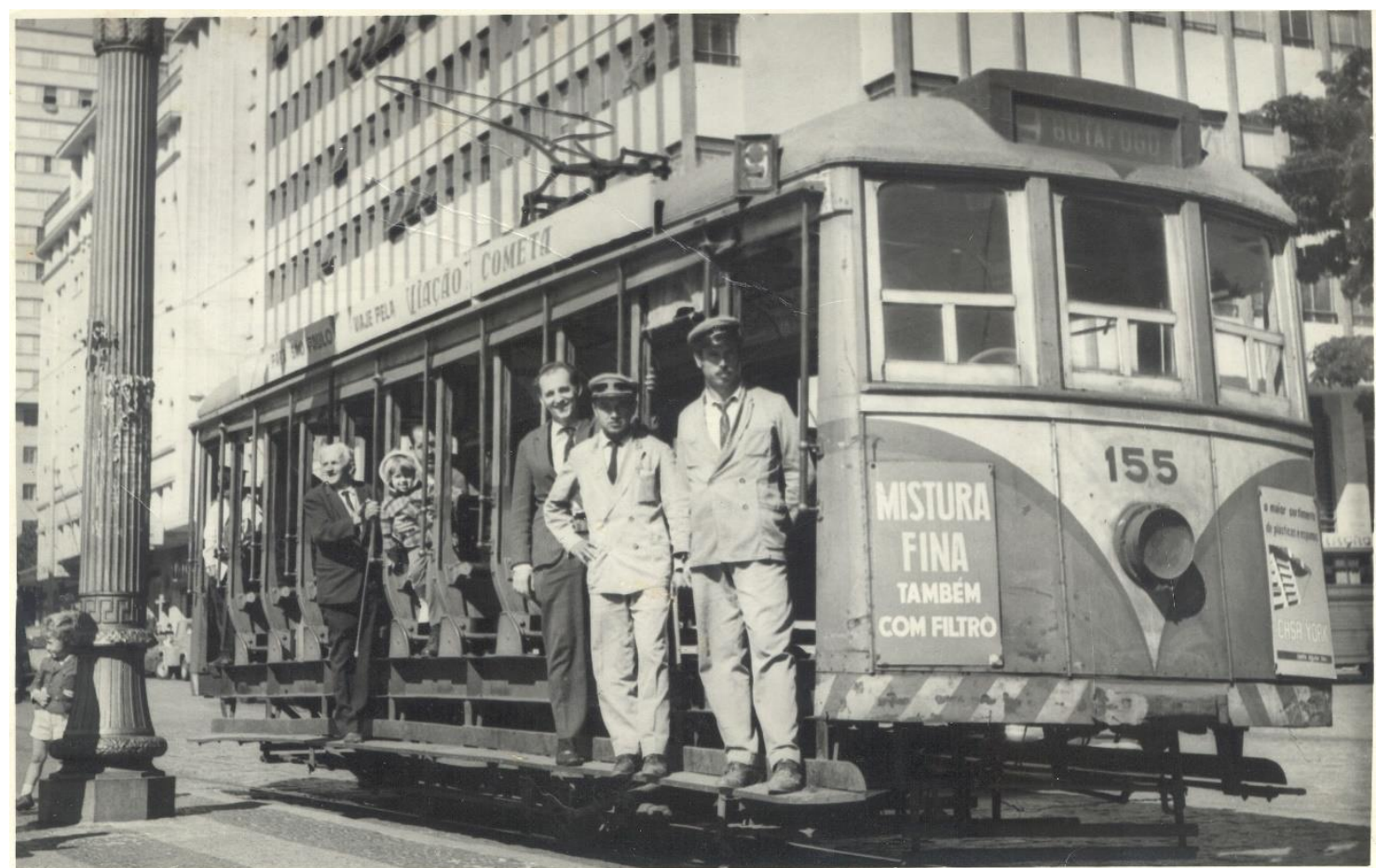


IMAGEM 07 - Goleiro Dimas, pai de Mestre Jahça, (Fotografia V8, Centro de Memória UNICAMP)

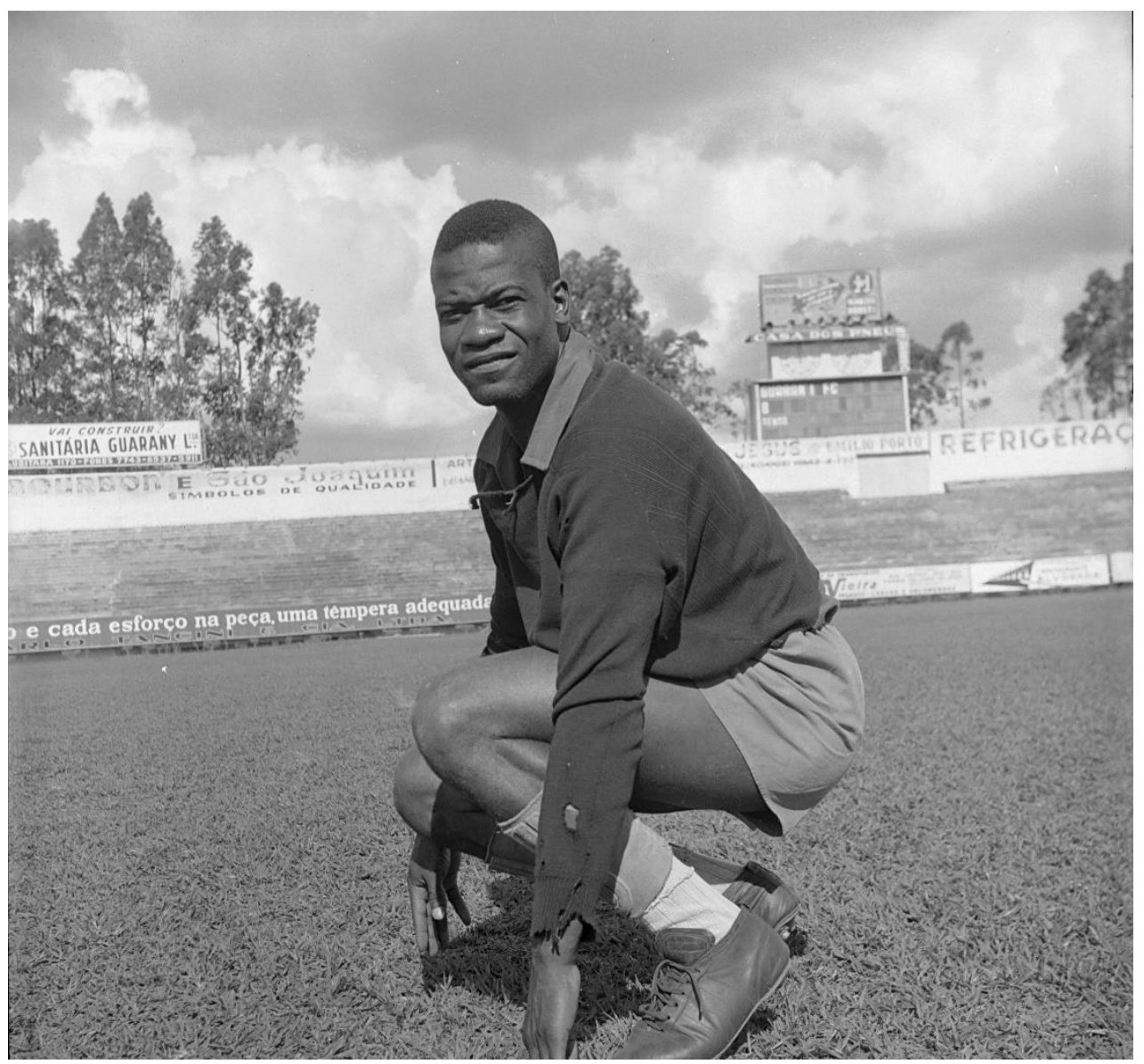

IMAGEM 08 - Estádio do Guarani, (Fotografia V8, Centro de Memória - UNICAMP)

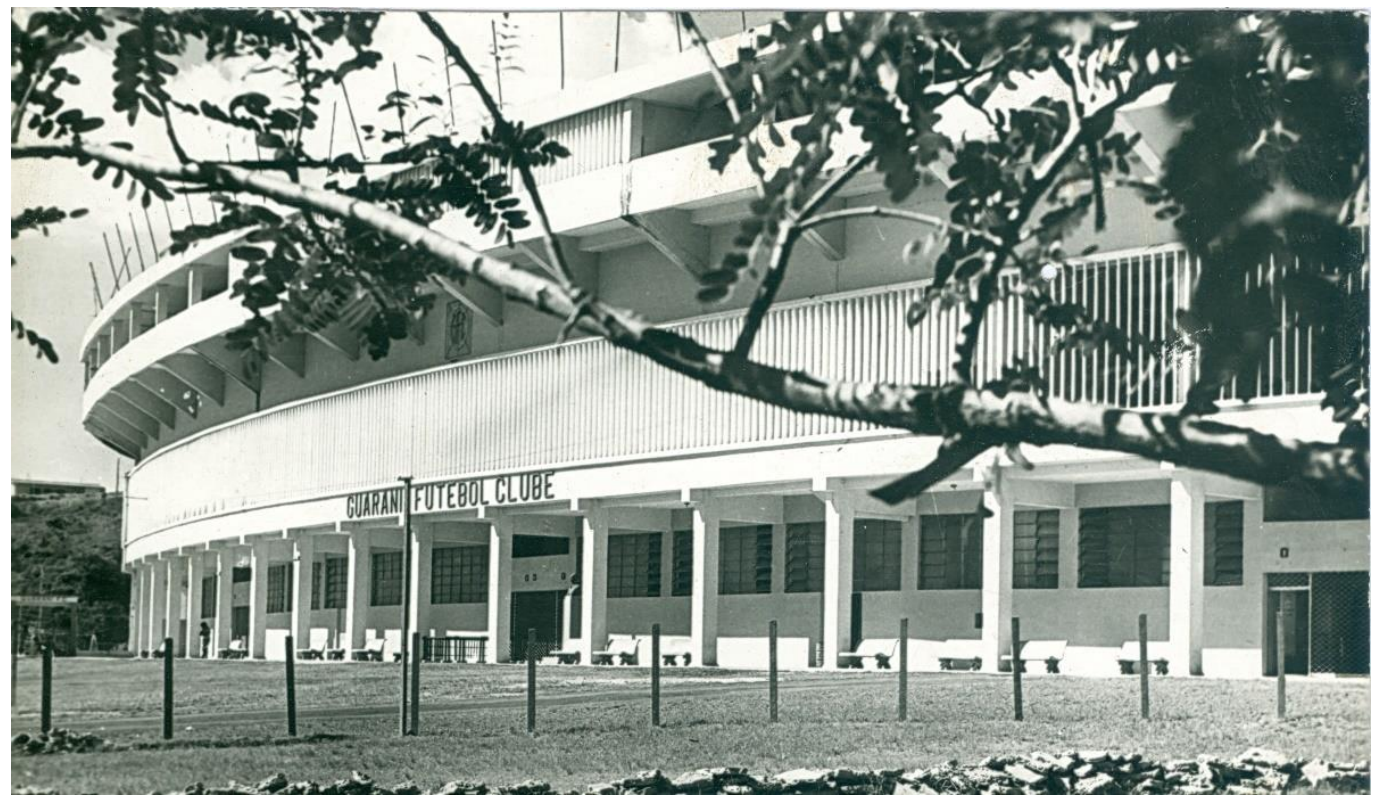

Rev. Iberoam. Patrim. Histórico-Educativo, Campinas (SP), v. 5, p. 1-26, e019041, 2019. 
IMAGEM 09 - Cartão postal de Campinas

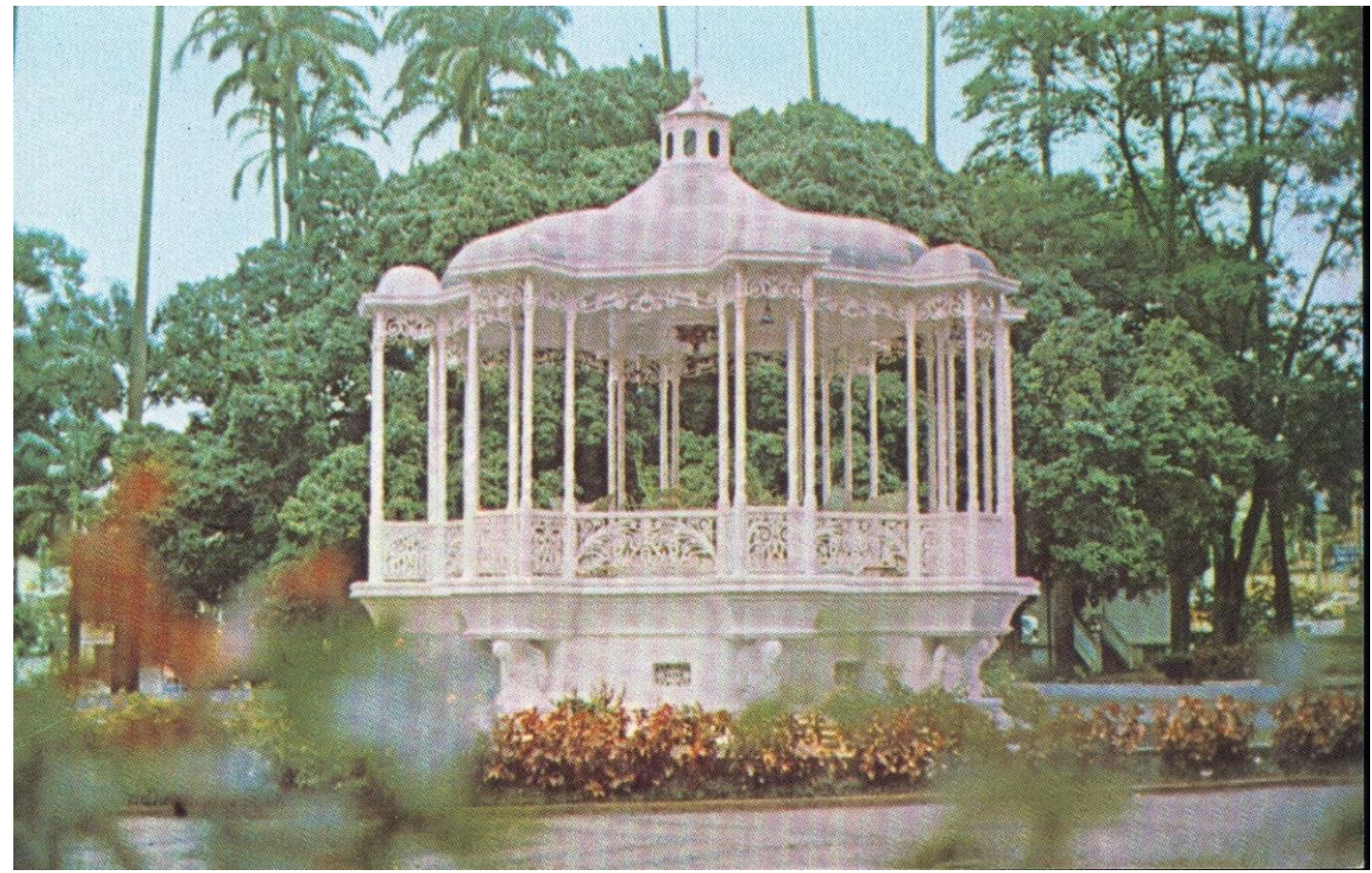

Fonte: Centro de Memória - UNICAMP

IMAGEM 10 - Fotografia da cozinha do Restaurante Universitário

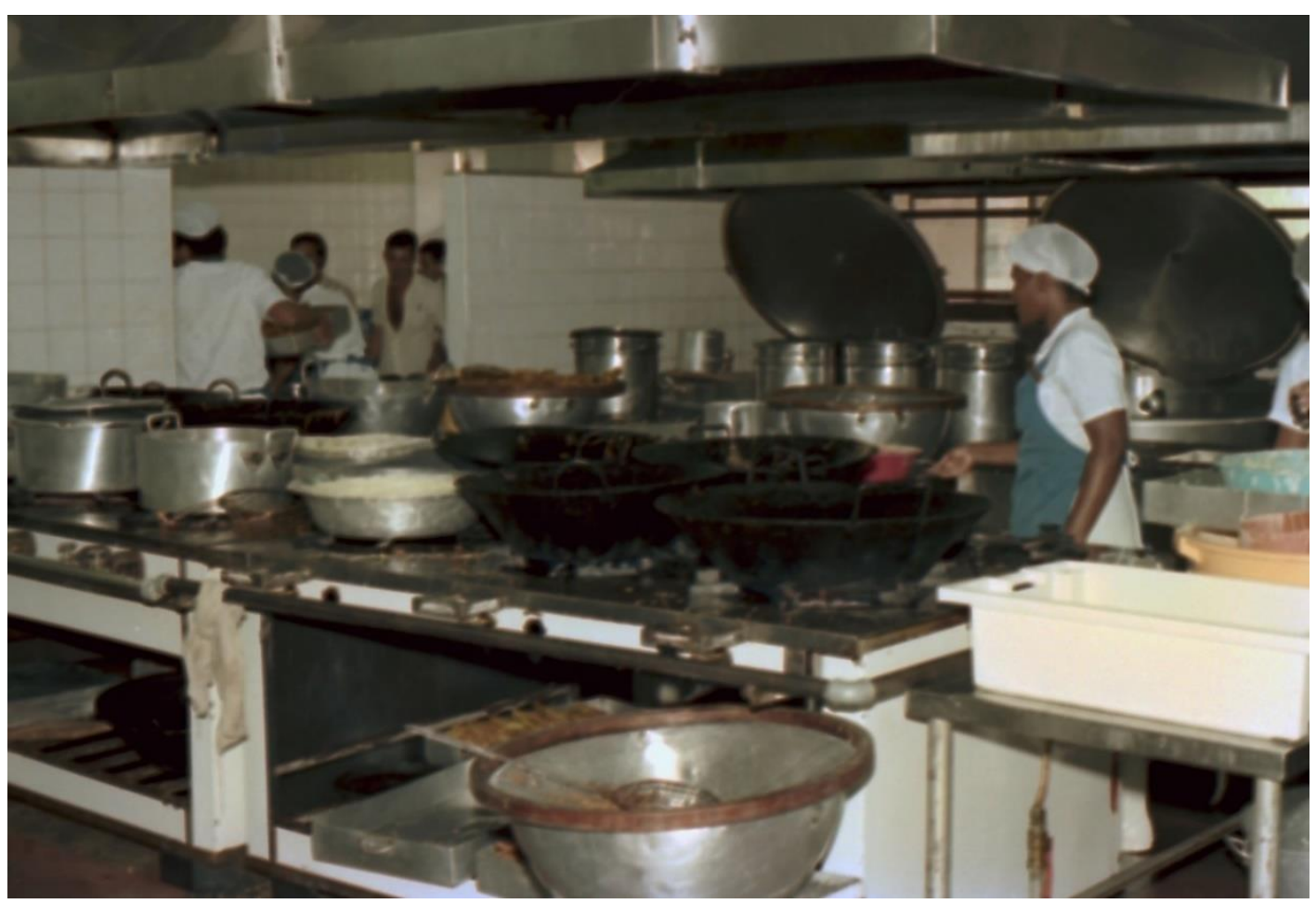

Fonte: SIARQ - UNICAMP

Rev. Iberoam. Patrim. Histórico-Educativo, Campinas (SP), v. 5, p. 1-26, e019041, 2019. 
IMAGEM 11: Still de Diário de Exus (Largo São Benedito, região central de Campinas)

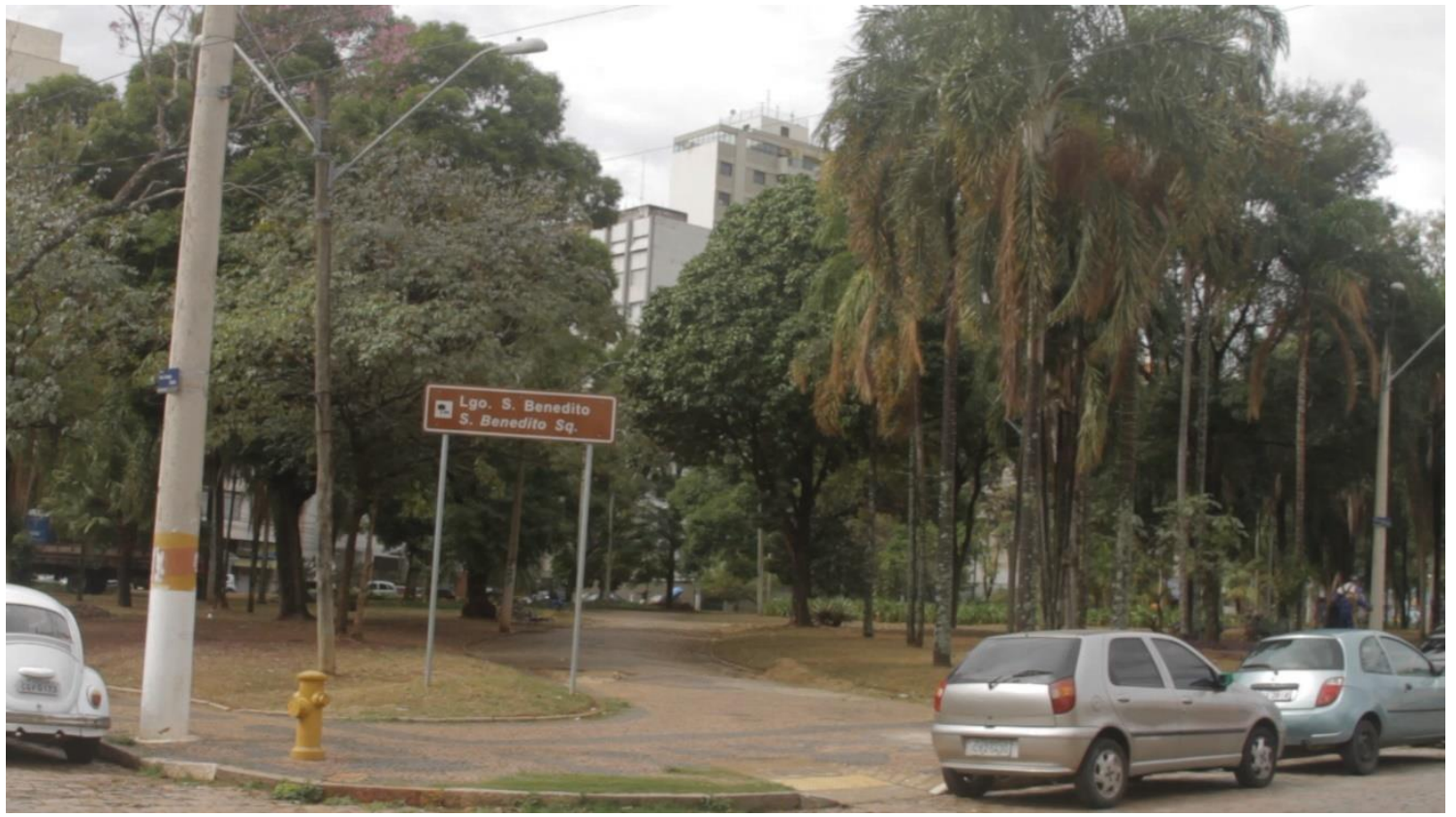

IMAGEM 12 - Still de Diário de Exus (Detalhe do quadro Elesbão, de Raquel Trindade, Museu do Café, de Campinas)

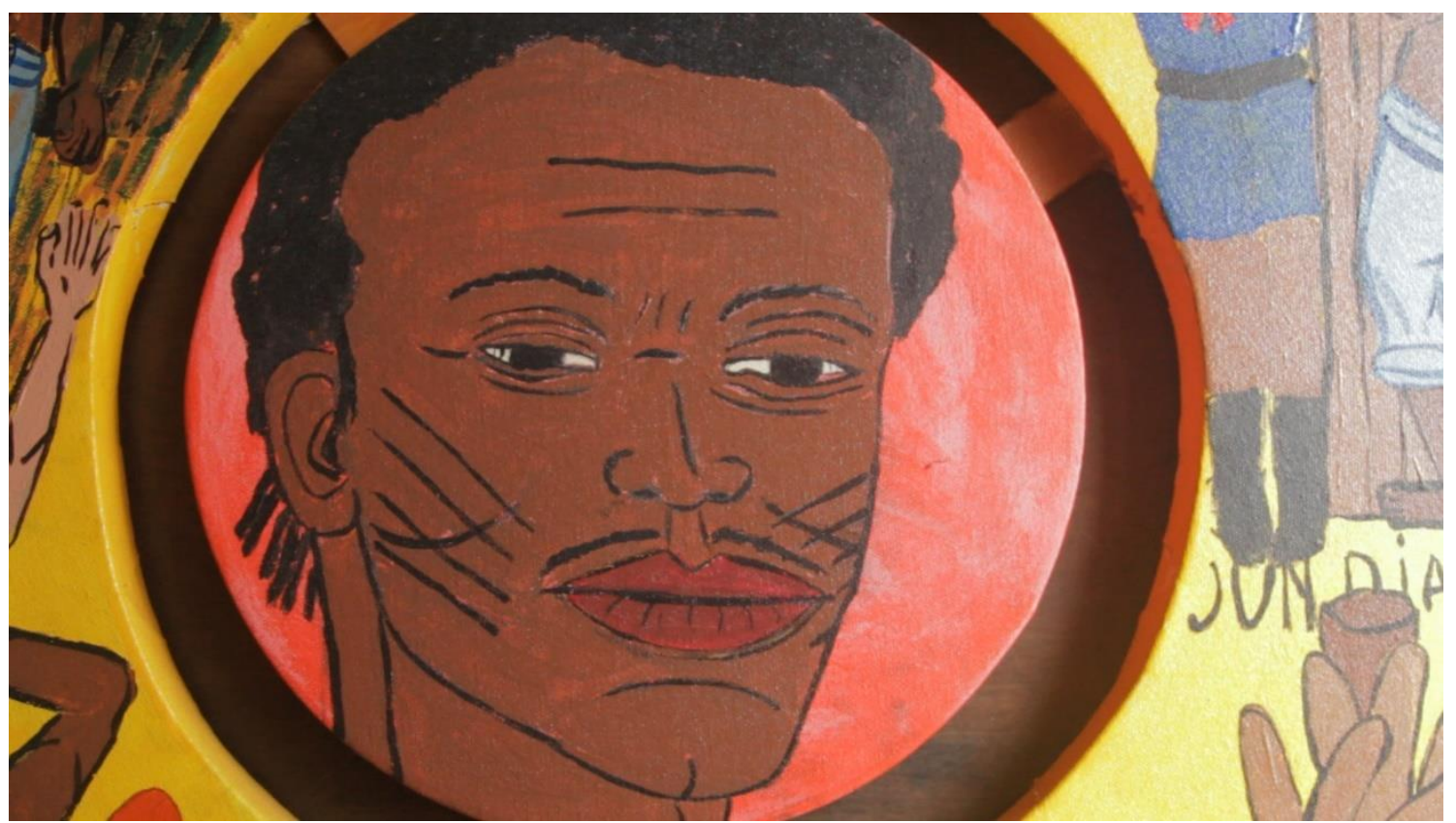


IMAGEM 13 - Mestre Jahça jogando capoeira

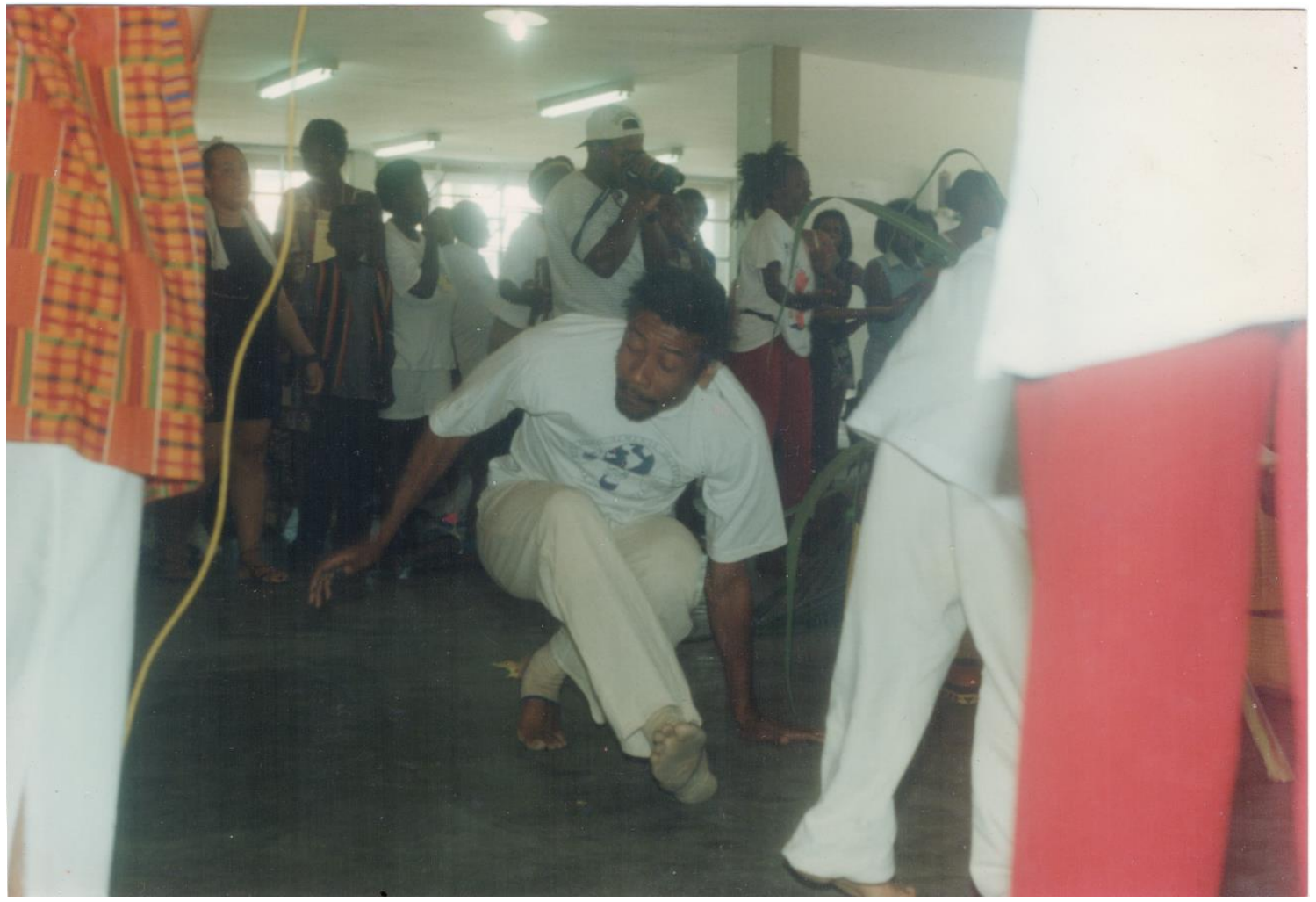

Fonte: Acervo pessoal de Mestre Jahça

IMAGEM 14: Still de Diário de Exus (Grupo de hip hop A Rua’nda)

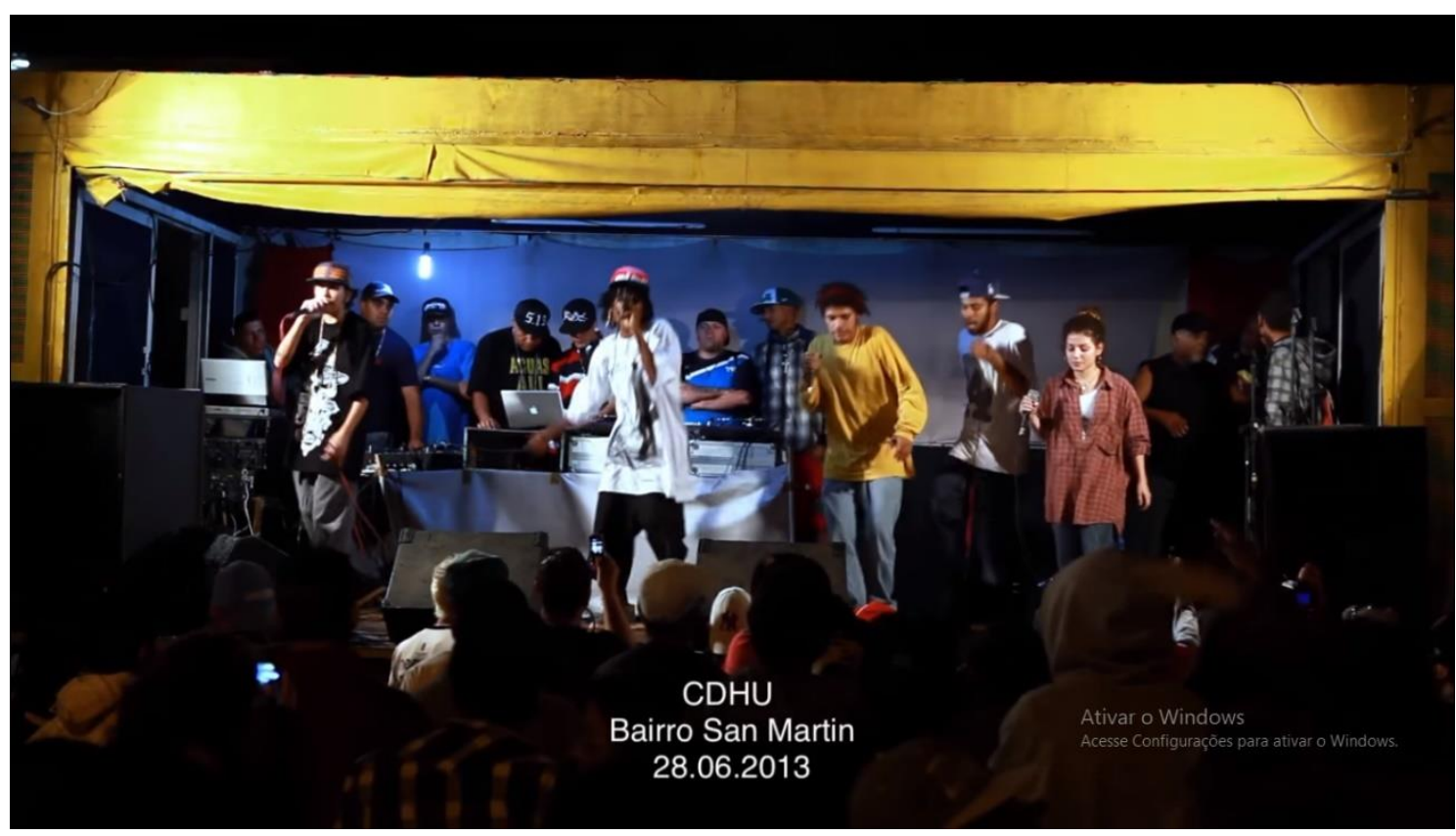




\section{Primeira versão do roteiro para montagem - Diário de Exus}

Conceito da montagem: Penso no Jahça e me veio a ideia de um processo pessoal pelo qual se deu a construção de seu corpo e do seu discurso por ele e disso participaram vários agenciamentos. Em seguida, pensei numa dupla apropriação desse corpo e desse discurso, no filme e na peça. Esses nossos gestos são também de defesa desse corpo e desse discurso. Estou empenhado em investir nessa dimensão construtiva, que evidencia uma construção, portanto, o documentário ativa um olhar que investiga o meu modo de olhar, e também se preocupa com os modos de olhar para câmera, e os modos como o modo de olhar para a câmera é uma forma de controle e de agenciamento do sujeito que possui a câmera.

Tela Preta - Letreiro inicial:

No início de 2013, iniciamos a realização desse documentário e do processo de criação da peça teatral Exus. Filme e peça versam livremente sobre o orixá Exu, uma das divindades dos terreiros de Candomblé e Umbanda, instaurado na religiosidade brasileira, a partir da diáspora africana. A divindade existe enquanto uma realidade imaginada e cultuada cotidianamente por meio de suas músicas, objetos rituais e um conjunto de histórias míticas. Exu dá, Exu tira, Exu briga, Exu ama, Exu mata, Exu castiga, Exu vinga. Do chão riscado e entreriscado com símbolos da divindade, aos altares que se fazem e se desfazem, aparecem e desaparecem as múltiplas faces de Exu. Nesta narrativa, à espreita e querendo devorar a todos nós, Exu nos convida a matarmos o pássaro de amanhã com a pedra que atiramos ontem. Laróyè.

\begin{tabular}{|c|c|}
\hline IMAGEM & SOM \\
\hline $\begin{array}{l}\text { 1. Imagens da cidade de Campinas, } \\
\text { do ponto de vista de um passageiro } \\
\text { de automóvel, em movimento. } \\
\text { (Senzala e Igreja - entre MVI 11, } \\
12 \text { e 13) - o plano deve terminar } \\
\text { no cruzamento (Encruzilhada) } \\
\text { Título do filme - "Diário de Exus" }\end{array}$ & $\begin{array}{l}\text { 1. Percussão coletada durante a } \\
\text { Lavagem da Escadaria, em } 2014- \\
\text { somente a percussão, sem os } \\
\text { cantos. } \\
\text { (Áudio Lavagem 2014) }\end{array}$ \\
\hline $\begin{array}{l}\text { 2. Plano-sequencia das imagens das } \\
\text { estátuas de Exu e Pomba Gira - } \\
\text { Debate - vídeo - GoPro } 1248\end{array}$ & 2. Sem áudio \\
\hline $\begin{array}{l}\text { 3. Plano-sequência da Grácia e a } \\
\text { equipe da peça, sentados no chão, }\end{array}$ & \\
\hline
\end{tabular}

Rev. Iberoam. Patrim. Histórico-Educativo, Campinas (SP), v. 5, p. 1-26, e019041, 2019. 
3. “... ai o outro vira e fala não... foi tirado tudo, do negro foi tirado sistematicamente a cidadania, no que ele fala isso no depoimento dele a luz do auditório apaga... e alguém da platéia grita EXU... continua"

4. Som sincrônico

5. Imagens de preparação do debate, plano geral da configuração do debate $-\mathrm{o}$ audio pode entrar, sem necessariamente estar em sincronia, até sincronizar - GoPro 1251, 1257, 1258 - ate 1263

6. Jaça/imagens de seu pai/imagens de casas de pau a pique/volta para Jaça. 


\begin{tabular}{|c|c|}
\hline & $\begin{array}{l}\text { trabalhava como empregada das pessoas e } \\
\text { ai meu pai, nessa, conheceu ela, ai } \\
\text { gostaram e eu vim nascer. Nasci lá, mas } \\
\text { vim para Campinas pequeno, seis meses } \\
\text { assim. } \\
\text { A nossa infância assim (eu - } \\
\text { infância/adolescência...) eu acredito que } \\
\text { na nossa época era bem mais infância né, } \\
\text { você não tinha essa violência, esse medo } \\
\text { de sair de casa, tinha aquelas brincadeiras, } \\
\text { o homem do saco, tinha uns medos, mas } \\
\text { era mais histórico né, hoje a gente tem } \\
\text { medo da violência violência mesmo né. }\end{array}$ \\
\hline $\begin{array}{l}\text { 7. A princípio, imagens sincrônicas } \\
\text { da entrevista. }\end{array}$ & $\begin{array}{l}\text { 7. Nosso problema sempre foi com, } \\
\text { mão na cabeça, olha o polícia, a } \\
\text { hora que você chega, é negrão né, o } \\
\text { negro era mais visto como o } \\
\text { submundo né, como o cara, o } \\
\text { marginal né, hoje o pessoal fala, os } \\
\text { movimentos, que a gente já soube } \\
\text { disso muito tempo, mas de uma } \\
\text { maneira boa, geralmente ver polícia } \\
\text { era mão para a cabeça, tomava blitz } \\
\text { né, } \\
\text { Isso com que idade o senhor tá falando? } \\
\text { Começou quando ia para os bailes, } 14 \text { e } 15 \\
\text { anos os bailes eram feitos em casa, nos } \\
\text { fundos de quintal né, então a gente ia } \\
\text { dançar e tal, e os bailes que tinham ai na } \\
\text { cidade né, as casas, não eram casas } \\
\text { noturnas, tinham os bancários né, tinham } \\
\text { uns clubes ai que os negros que eles, } \\
\text { alugavam, então semanalmente faziam um } \\
\text { baile para a comunidade né, que era onde a } \\
\text { gente se encontrava, trocava ideia, } \\
\text { Fazendo uma análise né, passamos pela } \\
\text { ditadura militar, passamos pelo DoI } \\
\text { CODI, passou por um monte de situação }\end{array}$ \\
\hline
\end{tabular}



em si, e gente vê que existe um sistema né, o negro era mais visado porque devido a aproximação com a escravidão, que acabou em 1888, eu nasci em 57 né, então era fácil falar negro quando não caga na entrada caga na saída, coisa de preto né, basta ser preto né, a mulher negra é boa de cama e tal, pra gente a agente ouvia muito isso né, era muito comum e aquela, racismo camuflado né, então a gente sentia mas, é, e a gente tinha o estereótipo do bandido né, viu é negro e tal né, era uma situação que tinha as classes, a elite né,

É por exemplo, quando eu fui para a Unicamp, pra trabalhar La, eu tinha 14 anos, então a gente estudou, se preparou, para trabalhar tipo num escritório, trabalhar como Office boy,

olharam para a gente, para o tamanho e tal, ah, vai para o bandejão, e ai vamos descarregar caminhão, ah pô, o que você tem contra isso?

Continuei trabalhando e estudando, é assim, você acredita que existe um sistema que vai avaliar o seu trabalho, a assiduidade, vai avaliar a sua pontualidade,

Você vai subir na carreira de alguma forma

Isso não existe né, se vê que com o tempo né, mas hoje avaliando eu vejo que tem uma história que por que que eu fui lá?

com o tempo, dois anos depois eu fui retirado lá pela polícia, perdi os documentos,

1416 anos, ... 17 eu fui, perdi os documentos e tal, falei para minha mãe, perdi os documentos lá na Unicamp, minha mãe falou deixa para lá, você acha ai né, passou uns dez dias veio um pessoal de Barão Geraldo, naquele tempo a polícia 
civil era, tinha uns, ela não era pintada, não sabia que era a polícia, tinha um camburão, era azul, a gente sabia por que era o jeito, ai foram lá, uns homens, uma hora apareceram, falou a gente precisa falar com você, falaram com a chefe lá, na época, a gente precisa levar ele, e daqui a pouco ele volta né, ai eu fui, falei para a chefia né, to indo com esses senhores ai mas eu volto, ai no caminho eles mudaram o discurso que tinha sido roubada uma casa em Barão Geraldo, que meus documentos tinham sido achados lá, que eu era ladrão, que o menino que a gente conhecia lá, que era da comunidade, que você conhece ele, que vocês são ladrão, eu falei não é isso e tal né, tentei explicar que, ai eles me levaram pro distrito em Barão Geraldo, acho que era $4^{\circ}$ na época, ai cheguei lá o policial falou ele tá falando que não é ele não, ai o delegado falou leva ele pra falar com o doutor Ferro, ai eu falei não, ai fomos para o primeiro distrito em Barão em Campinas, ai já fui algemado, tive que empurrar o camburão, tinha acabado a gasolina, nesse tempo eu falei, meu pai é o Dimas, jogador do Guarani e tal, é nada não sei o que né, ai no primeiro distrito, algemado, leva para falar com o doutro Ferro, ai desceu lá no porão, ai o cara pôs uns ferros lá, um pau de arara, pediu para eu tirar a roupa e tal né, pelado, os caras jogava água no meu...

meu pai foi lá, é o filho do Dimas mesmo, meu pai tinha, era conhecido né, goleiro e tal né, ai fiquei uma meia, um tempo interminável né, ai quando meu pai veio falou oh Dimas não sei o que, seu filho tá andando com... ai fiquei meio revoltado né, ai o que caiu ni mim na época assim, não adianta você participar de uma estrutura que você não tem defesa, dependendo da pessoa, ô podia ter ido alguém lá, não vamu com o menino e tal né, a própria estrutura, as pessoas que trabalhavam lá já 
acreditavam que eu era algum tipo de marginal.

8. Sons sincrônicos às imagens.

8. Cenas cortadas do grupo evocando Exu, os atores andam círculo, cortar para chegar a cena com Mestre Jaça - plano-sequência Mestre Jaça cantando e tocando berimbau. (ensaio 03.06 MVI_5713-4:10-08:50 -

Essa sequência também existe em outro arquivo NOVA PASTA $13: 16^{\prime}$

9. Sequência que Jaça e Grácia expõem que o espetáculo teria a cidade de Campinas

10. Plano-sequência com o grupo de rap Aruanda - (CDHU San Martin -MVI_002-02:02 -05:05)

11. Sequencia de imagens de arquivos - primeiro as imagens dos vídeos de maracatus e depois das fotografias de mestre Jaça como Exu e também os vídeos como Exu.

Aqui entrariam as sequencias de imagens da Casa Grande, da Senzala e da Igreja de Nossa Senhora da Conceição (Cartão Senzala e Igreja)
09. Som sincrônico - (Começa com Jaça e termina com Grácia - 00:007 - 02:12 continua no contexto da realidade (frase final) - Debate Cartão 02 - Câmera B. mvi 5796 - cartão 01 câmera a

10. som musical sincrônico

11. Eu fiquei perdido como ser humano e como pessoa né, eu via, como começou o movimento negro, os panteras negras, com Nelson Mandela e tal, ai que a gente começou com o grupo de teatro evolução, que hoje, você não tem o seu espelho na televisão, você não liga a televisão, na nossa época era menos ainda, você via a escrava apanhando, fugiu, não sei o que, apanhou.

O movimento nosso começa em Campinas (...) tinha os bailes a gente ia lá dançava nossas músicas, a gente tinha o grupo capoeira coquinho baiano, com o Mestre Godoy, Mestre Antonio, Mestre Tarzan vem da Bahia, que a gente via nas praças e tal, eu não me encontrava no meio, 
trabalhando na universidade, servindo

loiros e loiras, não via negro,

Campinas era uma cidade onde o preconceito era mais forte sempre e aqui que é terra de Barão mesmo, o último segmento a quebrar com a escravidão, pelourinho, Elesbão, a última praça a terminar com a escravidão, via o negro no começo, vou te mandar para Campinas, os castigos aqui eram pesados e ser negro aqui sempre, não é que foi difícil né, tinha a separação onde você andava e tal e ai quando começou a aparecer os grupos negros, o teatro Evolução, foi o primeiro trabalho, com o Natanael, o pessoal, começaram a trabalhar diretamente com dança afro, com o tema do negro, deixava crescer o cabelo, até então a gente alisava, deixava baixinho, ai os caras deixou o cabelo duro, e começou a descer os primeiros dredlocks, a gente começou a ter a primeira referencia,

Você vai ver a sua origem desde a Africa, como nós fazíamos balé Afro, dança afro, fizemos Classe Indefesa, então você vai na sua origem né, então me abriu um campo cultural pro teatro, dança, ai fui fazer capoeira, eu entrei mais no nosso universo né, do negro né, nossa origem, desde a África né, como a gente chegou aqui, reis e rainhas, todo um panteão mesmo que, que a nossa educação vem de 1500 para cá né, a partir de como o negro chegou como uma mercadoria escrava, a gente assimilou uma história dominador, é o que passa nas escolas, é o que a gente aprende, mas na nossa ancestralidade, nossa africanidade, a gente não sabe né, é apagado da nossa mente, isso você tem através de exercícios de meditação, você volta até isso através de exercícios de teatro mesmo, trabalhar não só com seu corpo mas com sua consciência interna (...) 
12. Som sincrônico

12. Sequência do Rodrigo - Exu é o dono da cozinha - (ensaio 03.02 11:06 até o final - MVI_5713), continua 5714 -00:00 - 02:02) -

Usar também trechos dessa mesma sequência no arquivo NOVA

PASTA - 06:55 - 10:10

13. Utilizar imagem de arquivo, Jaça como ExU- imagem em movimento em VHS e fotografia

Os três Exus

Ao final da fala do Jaça, já introduzir as imagens da Lavagem com a procissão.
13. O Exu é uma entidade cósmica, ele tem a função cósmica de fertilizar, de construir, de trazer a vida né, ele tem o falo né, como a mente humana humanizou tem um corpo humano, mas não teria um corpo humano, ele representa a sexualidade, sexualidade que fertilizou as estrelas, né, através de um gozo cósmico, criou todo um universo,

Exu não tem maldade, é o nome, Exu, podia ser outro nome

Mestre, como se deu a sua aproximação com esse conhecimento, com esses deuses africanos, com o Exu e outros no candomblé? Foi no mesmo momento que você começou com a capoeira e o teatro? A verdade é que tem toda a descoberta de um novo mundo, e a formação de um novo ser, não é?

Entra aquela questão, por que que a gente ta aqui, né? Eu acredito que todos temos um porque né de ta vivo, de existir né, de passar por esse período de turbulência né, eu acredito assim, foi fase né, uma quando eu entrei na Unicamp, uma quando eu conheci o Natanael (HOMEM NEGRO DE CAMISETA AZUL), outra com o Carlos Kiss, a gente montou o Urucungos, hoje a gente já tem trabalho junto, mas se essas pessoas não tivessem aparecido na 
minha vida, num certo momento, o meu trajeto, como ser humano, teria sido outro

Tudo começa assim, com o Liberdade, Canto e Dança, se eu não tivesse ido para o Liberdade, canto e dança, não teria ido ao Urucungos, não teria conhecido o Carlos Kiss (HOMEM NEGRO DE CABELO COMPRIDO), não teria feito capoeira, não teria feito nada né, então eu acredito também na transcendência da alma, aquela coisa também da nossa historia né, nada morre, a gente transfere a essência para o outro corpo, uma outra matéria, já ta na nossa historia, a historia do negro né, ta na historia de todo mundo mas, com entendimentos diferentes.

eu aprendi a reconhecer o que é nosso e correr atrás do que é nosso, através da arte, através da consciência corporal, através do desenvolvimento do corpo, da mente,

para mudar uma estrutura depende de cada um, a gente trabalha para isso.

14. O EXU para mim, ele é, EU SOU O EXU.
14. Cenas da Lavagem - o final deve ser o sujeito e a samambaia 


\section{FICHA TÉCNICA DO FILME}

Título: Diário de Exus (24min)

Sinopse: O documentário atualiza o mito afro-brasileiro de Exu, tomando como ponto de partida o registro do processo de criação da peça de teatro Exus. Seu protagonista, o ator e funcionário aposentado do Instituto de Artes, Mestre Jahça, é o fio condutor que conecta os diferentes lugares onde habita esta entidade na cidade de Campinas.

Direção, roteiro e produção: Gilberto Alexandre Sobrinho

Direção de fotografia: Felipe Bomfim

Som: Victor Negri

Montagem: Rodrigo Faustini

Assistente de direção e produção: Alessandro Oliveira

Com o Grupo Pindorama, peça teatral Exus, direção de Grácia Navarro

Apoio: FAEPEX/UNICAMP e Instituto de Artes/UNICAMP

\section{Participação em Festivais, mostras e exibições:}

2015 - Projeção no MIS, Museu da Imagem e do Som (Campinas, SP) - Lançamento

IMAGEM 15 - Exibição do documentário no MIS/Campinas

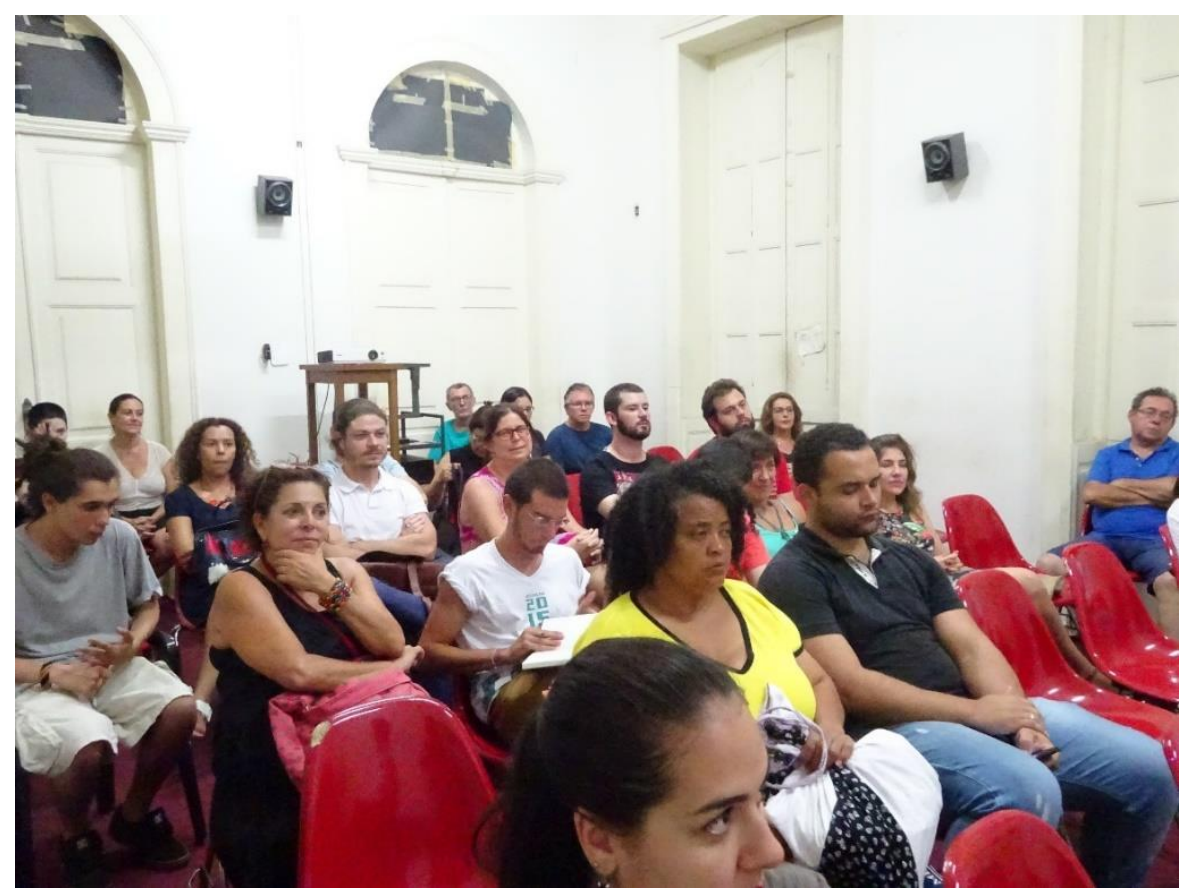

Fonte: Acervo pessoal Gilberto Alexandre Sobrinho) 


\section{$(\mathrm{cc})$ EY}

2015 - 9 $9^{\text {a }}$ Mostra Curta Audiovisual de Campinas (Campinas, SP)

2015 - Mostra Cineurge de Filmes Negros (Cornélio Procópio - PR)

2015 - $10^{\circ}$ CINEOP - Mostra de Cinema de Ouro Preto (MG)

IMAGEM 16 - Apresentação do documentário no $10^{\circ}$ CINEOP - Ouro Preto.

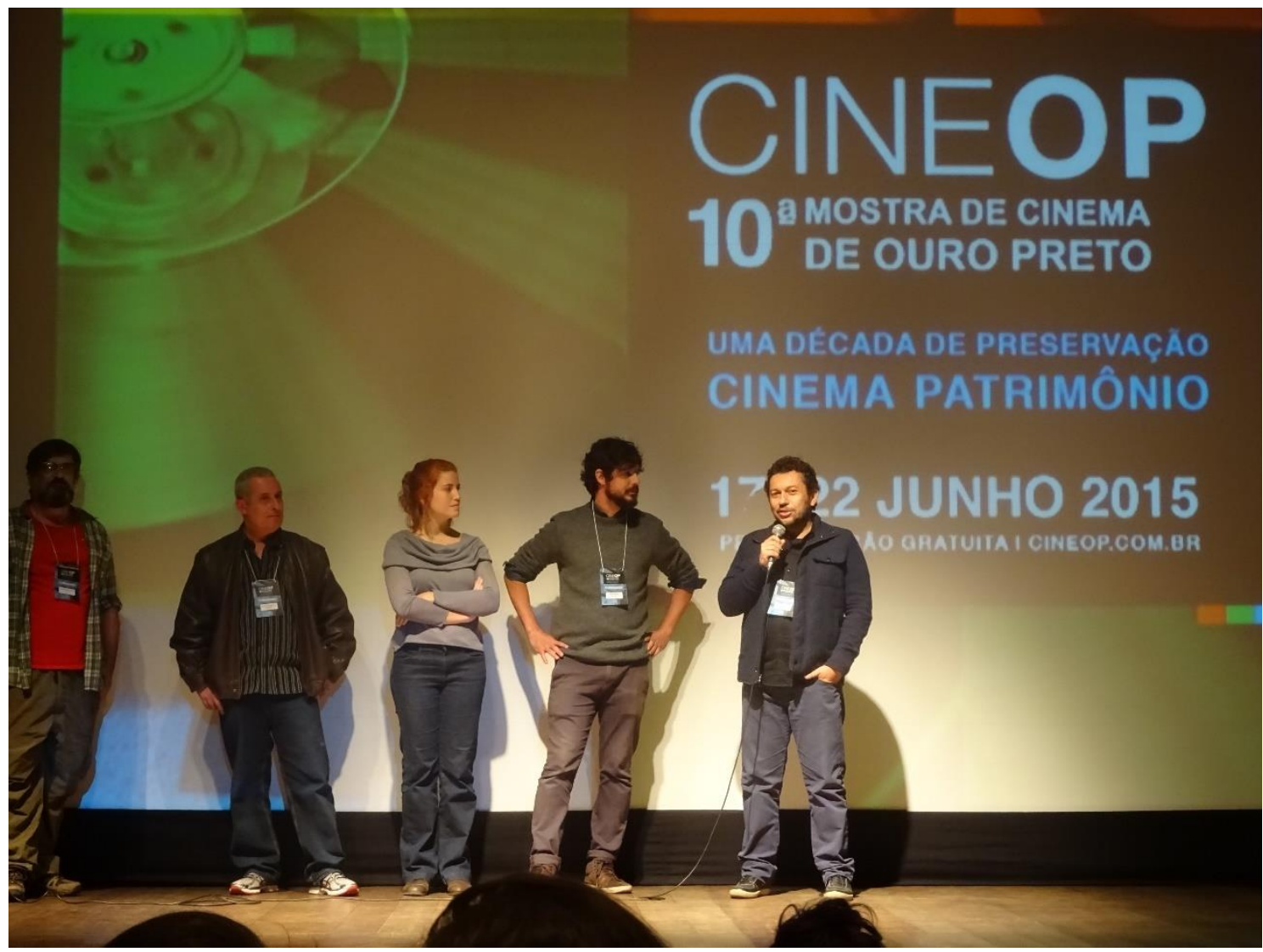

Fotografia: Nanci Barbosa.

2015 - Projeção na Galeria de Artes do Instituto de Artes - GAIA

2016 - $9^{\text {a }}$ Mostra Luta (Campinas - SP)

2016 - $6^{\circ}$ Cine Debate - Núcleo Afro-Brasileiro de Ilha Solteira (NABISA)

2017 - Projeção no Espaço CHÃO (São Luís, MA)

2017 - Projeção ADUNICAMP - Associação dos docentes da Unicamp (Campinas, SP)

2017 - Projeção Cineclube Vagalume, Faculdade de Ciências e Letras, Unicamp - Limeira (Limeira, SP)

2019 - Cineclube Terracota - Campinas - SP 
2019 - SESC Campinas - SP

2019 - Centro Cultural Brasil - Moçambique, Maputo - Moçambique

IMAGEM 17 - Material de divulgação da exibição da Trilogia Afro-Campineira em Maputo.

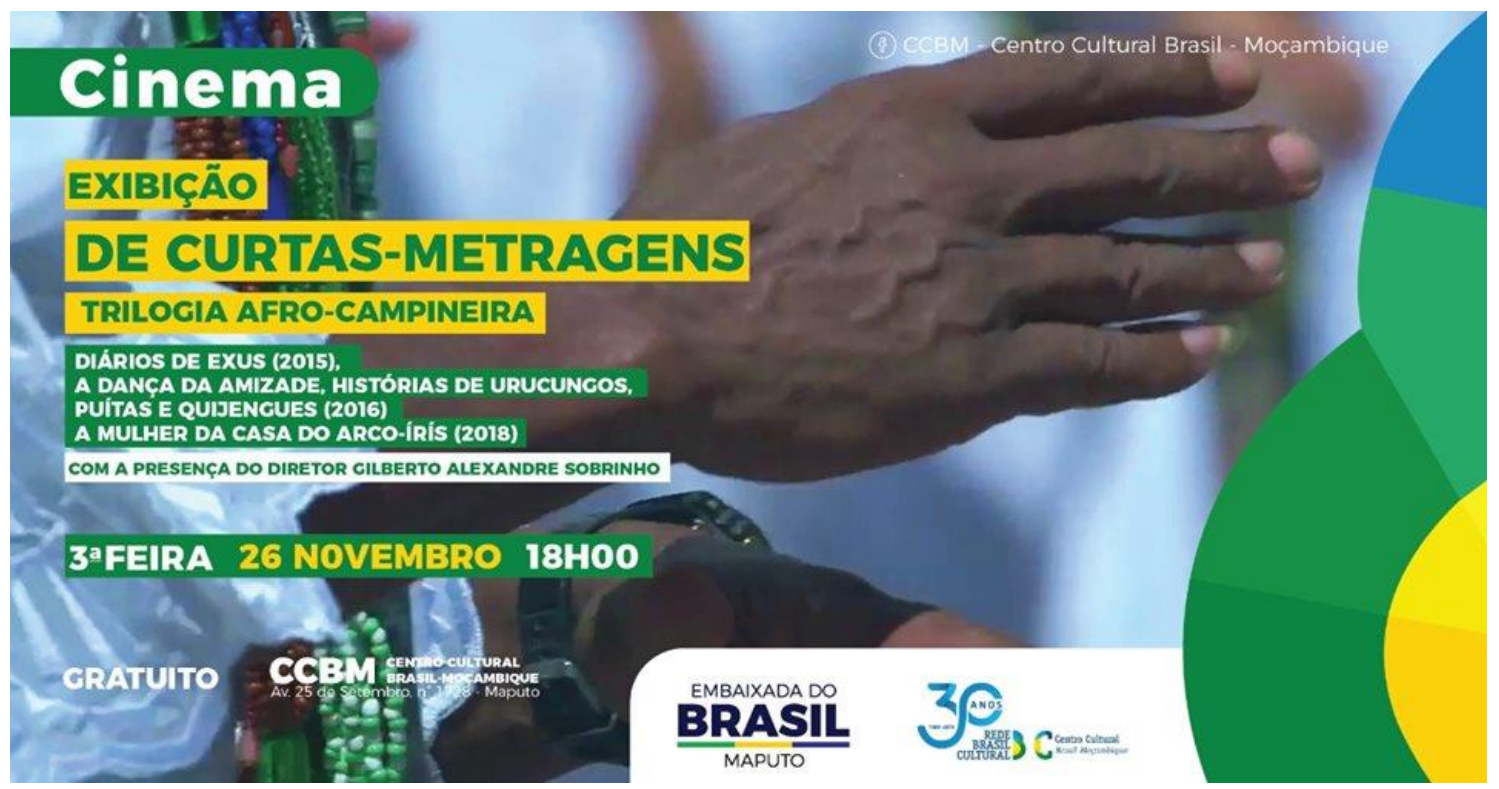

\section{Publicações relacionadas ao curta-metragem:}

OLIVEIRA, Alessandro, NAVARRO, Grácia. A tensão entre o sagrado e o fazer teatral: uma reflexão a partir do espetáculo Exus, do Grupo Pindorama. Urdimento, v.2, n.27, p.249-268, dezembro, 2016.

SOBRINHO, Gilberto Alexandre, NAVARRO, Grácia, KOPELMAN, Isa. Exu: Da investigação da teatralidade na oralidade popular brasileira à tecedura dramatúrgica contemporânea. In: VII Reunião Científica - ABRACE, 2013, Belo Horizonte. Memória Abrace Digital, 2013. p. 01-08. (http://www.portalabrace.org/viireuniao/dramaturgia/NAVARRO_Gracia_Maria_KOPELMAN_ Isa_SOBRINHO_Gilberto_Alexandre.pdf)

Distribuição:

O curta-metragem está disponível no Youtube:

https://www.youtube.com/watch?v=EDOzUro7EDs

Recebido em: 24 de dezembro 2019

Aceito em: 27 de dezembro de 2019 